\title{
FLINT INVENTORIES OF LUBLIN-VOLHYNIAN CULTURE BURIALS FROM SITES 1A AND 2A IN STRZYŻÓW, HRUBIESZÓW DISTRICT, IN LIGHT OF THE ARCHAEOLOGICAL AND TRASEOLOGICAL ANALYSIS
}

\section{Abstract}

Mączyński P. and Zakościelna A. 2017. Flint inventories of Lublin-Volhynian culture burials from sites 1A and 2A in Strzyżów, Hrubieszów district, in light of the archaeological and traseological analysis. Sprawozdania Archeologiczne 69, 327-352.

Flint products are a regular element of the grave goods in Lublin-Volhynian culture (further L-VC), at the same they are attributes primarily of male burials. Some well-equipped burials of adult males are accompanied by numerous and diverse flint inventories, discovered in various locations on the dead, including macroblades and dagger-blades made of Volhynian flint, lying on the chest, interpreted as objects of prestige. So far, these products have very rarely been subjected to traseological analyzes. This article provides the results of functional analyzes of flint inventories of several graves of the L-VC classical phase, from sites IA and 2A in Strzyżów, Hrubieszów district.

Keywords: Lublin-Volhynian culture, grave inventories, flint products, microwear analysis, utilitarian and non-utilitarian functions

Received: 28.02.2017; Revised: 16.05.2017; Accepted: 03.07.2017

\footnotetext{
* Institute of Archaeology, Rzeszów University, Moniuszki st. 10, 35-015 Rzeszów, Poland; archeolublin@ gmail.com

** Institute of Archaeology, Maria Curie-Skłodowska University; M.C. Skłodowska sq. 4, 20-031 Lublin, Poland; a.zakoscielna@gmail.com
} 


\section{INTRODUCTION}

In the field of Polish archaeology, the method of microscopic analysis of flint artefacts has been used since the 1970s (Drobniewicz 1978; 1979; Małecka-Kukawka 2001, 1821). Despite the relatively recent use of microwear analysis by Polish researchers, flint inventories related to Lublin-Volhynian culture were rarely subjected to functional analyzes.


Fig. 1. Strzyżów, Hrubieszów district. A - plan of the settlement-funeral complex:

1-3 - single burials on site IA and II; 4 - cemetery on site 2A. B - plan of the cemetery Strzyżów 2A (according to Zakościelna 2010) 
The necessity of carrying out such studies was suggested already in the 1990s (Zakościelna 1996, 108), but the first microscopic observations were made in 2003 by Natalia N. Skakun, who analyzed 16 trapezes from grave 4 in Książnice, Busko-Zdrój district Zakościelna 2010, 139, footnote 9). Further analyzes - also by this researcher - concerned the deposit of macroblades made of chocolate flint, discovered in Krowia Góra, Sandomierz District (Skakun et al. 2008, 430-433). Moreover, this issue was presented several times by various authors at conferences organized within the Lithic Workshops of Flintreaders Society SKAM (Mączyński 2015, 17; 2016, 29; Wilk and Kufel-Diakowska 2016a, 23). Recently published are the results of traseological analyzes of several artefacts from burial inventories of L-VC in Książnice 2, Busko Zdrój district, and this initiated a discussion about their functions (Wilk and Kufel-Diakowska 2016b).

With this article, which presents the results of traseological observations of several burial inventories from sites IA and 2A in Strzyżów, on the one hand, we want to supplement the catalog of microwear analyzes of LV-C flint materials, and on the other, to participate in this discussion.

\section{STRZYŻÓW, SITES IA AND 2A}

The village of Strzyżów, Hrubieszów district is located in the area of Horodło PlateauRidge, the mesoregion of West Volhynian Upland (Kondracki 1981, 260, 345). Sites IA and 2A are a part of large, multicultural, settlement-funeral complex, occupying the entire left bank of the Bug River fluvial Terrace, on the section of nearly $3,5 \mathrm{~km}$, from the church in Strzyżów to the first fields of Rogalin village. The terrace is raised about $6 \mathrm{~m}$ above the bottom of the valley. The greatest density of artefacts occurred in the section of about $1 \mathrm{~km}$ long and $300 \mathrm{~m}$ wide, east of the "Strzyżów" sugar refinery (Fig. 1: A). The first record about the site and discovery of the remains of L-VC settlement dates back to 1922 when the grave of this culture was accidentally exposed (Podkowińska 1960, 40). Excavations were carried out in two main campaigns: in the second half of the 1930 s by Zofia Podkowińska (1935-1937 and 1939), then in the first half of the 1960s by Jan Gurba (1958, 1961-1963) and Jerzy Głosik (1961). Among the varied remains of the abundant prehistoric settlements were found those from the classical and late phase of L-VC (Kulesza 2008, and the further bibliography), single graves located in various locations and a cemetery of seven graves (Zakościelna 2010, further bibliography).

\section{PRESENTATION OF MATERIALS}

Site IA, grave 1/1961 (studies of Jan Gurba, 1961) - a double human grave located in the western part of the settlement, amid utility pits. Skeletons were located in foetal positions, face to face, with heads in a southerly direction (Fig. 2: 1). On the left side was an adult woman, on the right an adult man. Above the heads and legs of the dead was located 

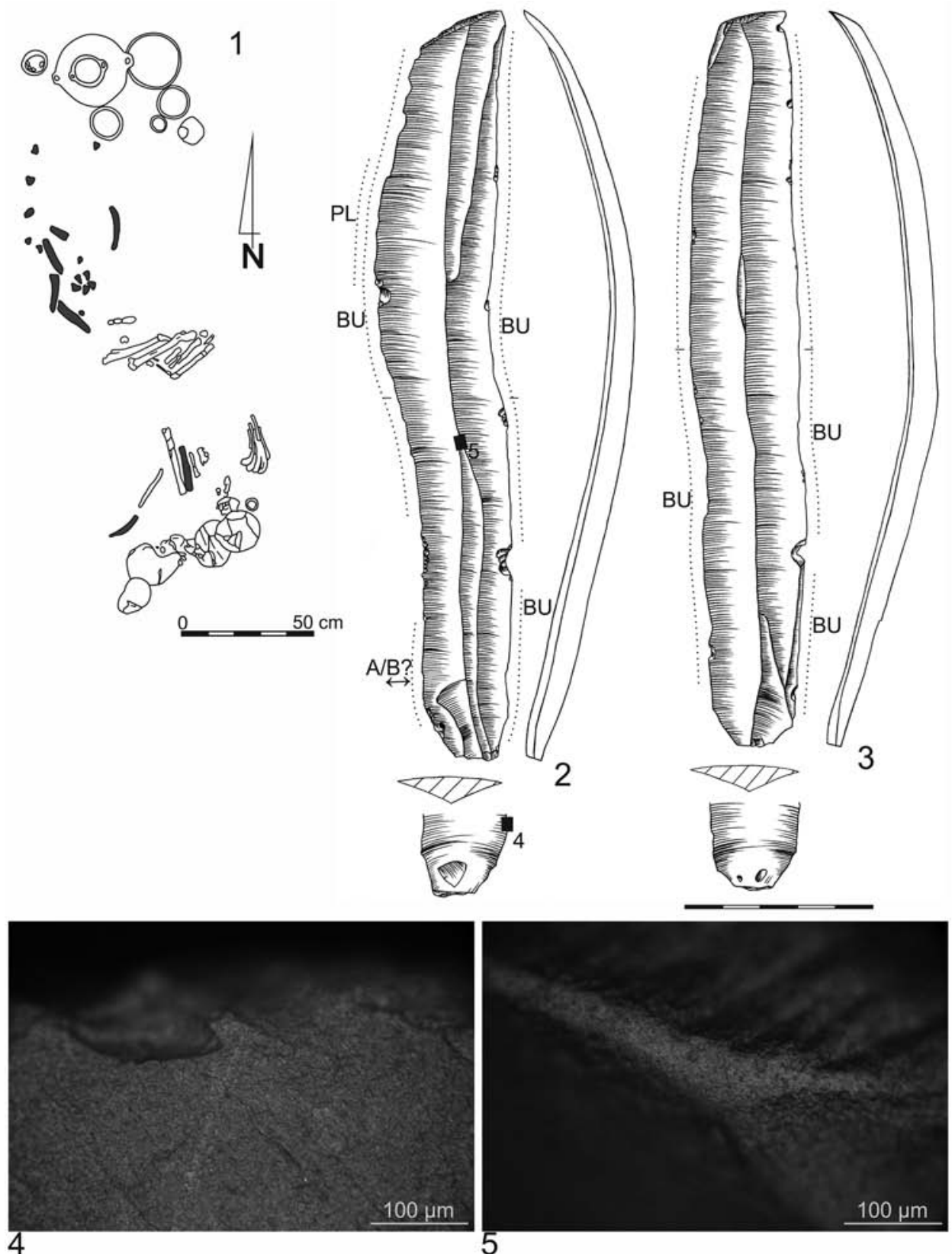

Fig. 2. Strzyżów IA. 1 - plan of the grave No. 1/1961; 2, 3 - flint blades; 4 - traces of polish visible on the ridge, indicating bearing or the use of wrapping; 5 - use-wear traces, bright scratches indicating the use of the tool in processing of hard material of animal origin. Magnification $\times 200$ (objective $\times 20$ ). Drawn by A. Zakościelna, P. Mączyński, photographed by P. Mączyński. Legend: $\leftrightarrow \mathfrak{\imath}$ - motion; A/B - antler/bone; BU - butchering; $\mathrm{HA}$ - hafting; $\mathrm{HI}$ - hide; $\mathrm{M}$ - meat; $\mathrm{PL}$ - plants; $\mathrm{WO}$ - wood; $\mathrm{SH}$ - sheath; $\mathrm{SM}$ - soft material 
a set 10 vessels, of which 8 were reconstructed. At the woman's skull there were 2 copper earrings, with the man - 21 products made of Volhynian flint, including 8 blades, 1 endscraper on a blade (Fig. 2: 2, 3; 3: 1-4; 4: 1-3) and 12 arrowheads (“... 9 triangular and 3 chisel-shaped, made of chocolate flint” - Głosik, Gurba 1963, 361; arrowheads are missing). We do not know the exact position of the particular flint objects on the dead. Based on the plan of the grave it can be only said that one long blade lay behind the man's head, another (the longest?) along the left humerus, and the remaining blades and arrowheads were located on the continuation of his foot (Głosik and Gurba 1963, fig. 3; Zakościelna 2010, tab. LII). For traseological analysis 8 blades and an endscraper were available (Fig. 2: 2, 3; 3: 1-4; 4:1-3).

Flint inventory:

1. Scarred blade with an irregular course of both edges; facetted butt, domed bulb with bulbar scar, scar of platform edge trimming; incurved in the middle part, cortical tip, triangular-trapezoidal in cross-section; dimensions: $200 \times 32 \times 8$ mm (Fig. 2: 2).

2. Scarred blade with a regular course of both edges; facetted butt, domed bulb with bulbar scar, scar of platform edge trimming; incurved in the middle part, cortical tip, triangular in cross-section; dimensions: 196 × 29 × 8 mm (Fig. 2: 3). Blades No. 1 and No. 2 were removed from one core.

3. Scarred blade with an irregular course of both edges; dihedral butt, domed bulb with bulbar scar, scar of platform edge trimming; incurved in the middle part, triangular-trapezoidal in cross-section; dimensions: $187 \times 33 \times 7 \mathrm{~mm}$ (Fig. 3: 1).

4. Scarred blade with parallel course of edges; plain butt, domed bulb, scar of platform edge trimming/rubbing; incurved in the middle part, trapezoidal in cross-section; dimensions: $158 \times 25 \times 6 \mathrm{~mm}$ (Fig. 3: 2).

5. Scarred blade with an irregular course of edges; dihedral butt, domed bulb with bulbar scar, scar of platform edge trimming; incurved in the middle part, triangular-trapezoidal in cross-section; dimensions: 153 x 26 x 6 mm (Fig. 3: 3).

6. Scarred blade with a parallel course of edges; dihedral facetted butt, domed bulb, scar of platform edge trimming; incurved in the proximal part, trapezoidal in cross-section; dimensions: $147 \times 23 \times 6$ mm (Fig. 3: 4).

7. Scarred blade with a parallel course of edges; dihedral facetted butt, slightly domed bulb, scar of platform edge trimming; incurved in the proximal part, partly cortical tip, trapezoidal in cross-section; dimensions: 144 x 24 x 7 mm (Fig. 4: 1). Blades No. 6 and No. 7 form a refitting

8. Scarred blade with a regular course of edges; facetted butt, domed bulb, scar of platform edge trimming; incurved in the proximal part, trapezoidal in cross-section; dimensions: $139 \times 26 \times 5$ mm (Fig. 4: 2).

9. Endscraper with a strongly rounded, semi-abrupt endscraper front, made on a massive blade with a partly preserved crest, multi-scarred butt (facetted), strongly domed bulb with bulbar scar, scar of platform edge trimming; incurved in the proximal part, 

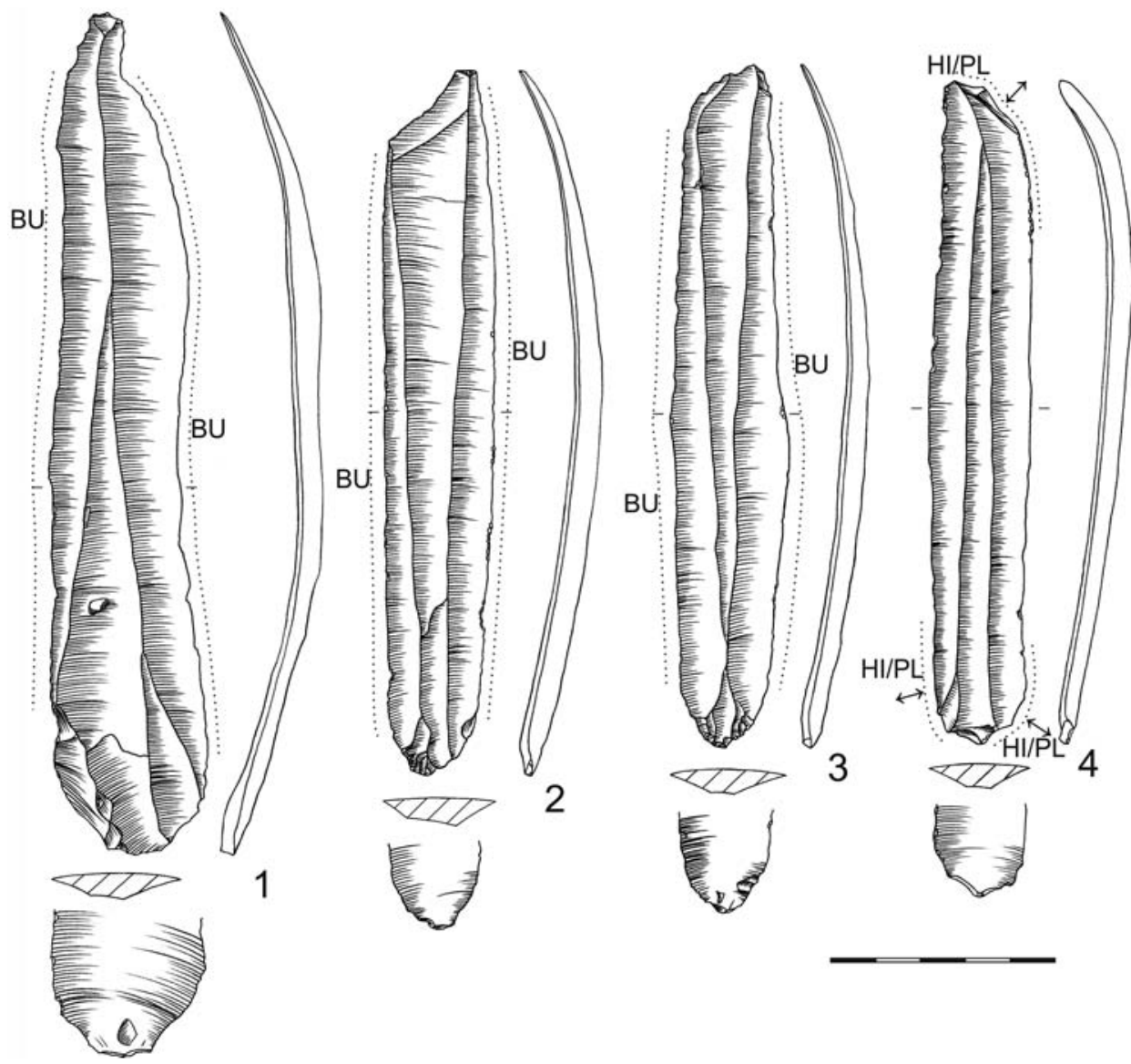

Fig. 3. Strzyżów IA. Inventory from grave No. 1/1961: 1-4 - flint blades. Drawn by A. Zakościelna, P. Mączyński

trapezoidal in cross-section; dimensions: $124 \times 28 \times 11 \mathrm{~mm}$, height of endscraper front: $5 \mathrm{~mm}$ (Fig. 4: 3).

Site 2A - cemetery (studies of J. Gurba 1962). The site was located in the northwestern part of the settlement complex, outside the range of the Lublin-Volhynian culture settlement, which is 300-400 meters away. Excavations covered a strip between the narrow-gauge railway embankment (in the south) and sewage tanks of sugar refinery (in north) (Fig. 1: A). On the surface of about $50 \mathrm{~m}^{2}$ seven graves were discovered, five of which formed compact cluster. In central part was located the grave No. 3, containing burial of adult male, and on its both sides, in distances ranged from 2,5 to 4,5 $\mathrm{m}$, in pairs were placed the graves: No. 1 (female, maturus) and No. 2 (adult male) - on the eastern 

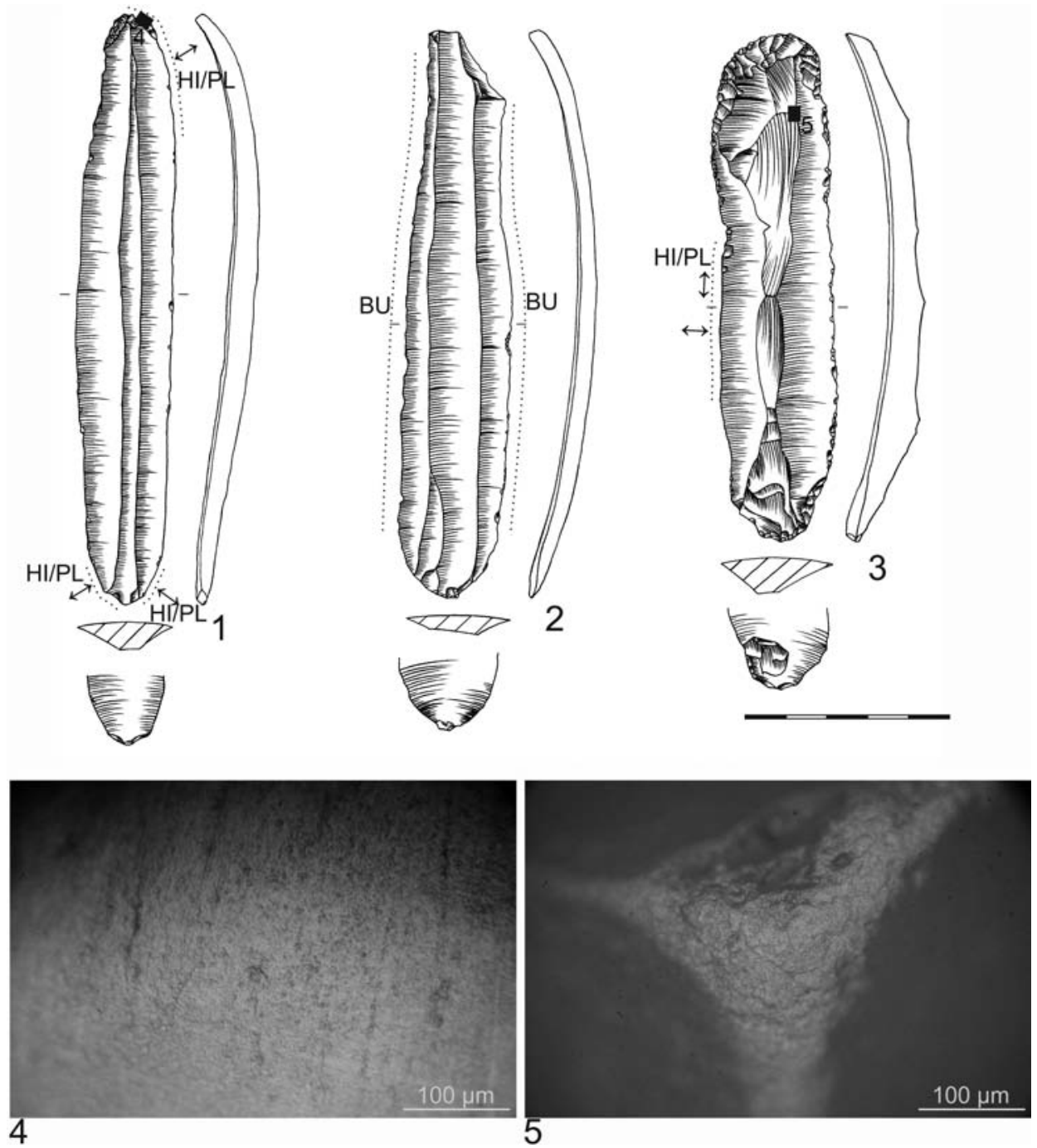

Fig. 4. Strzyżów IA. Inventory from grave No. 1/1961: 1; 2 - flint blades; 3 - endscraper; 4 - use-wear traces related to scraping of hides or dry plants; 5 - traces of polish visible on the ridge, indicating bearing or the use of wrapping. Magnification $\times 200$ (objective $\times 20$ ).

Drawn by A. Zakościelna, P. Mączyński, photographed by P. Mączyński

side, as well as the graves No. 5 (female?, maturus) and No. 6 (adult male?) - on the western side (Fig. 1: B). Outside of this layout was located the grave No. 4 (preserved only in the form of concentration of vessels), 10 meters distant and to the west of the central grave, and 4 meters from grave No. 5, defining the western boundary of the concentration. 

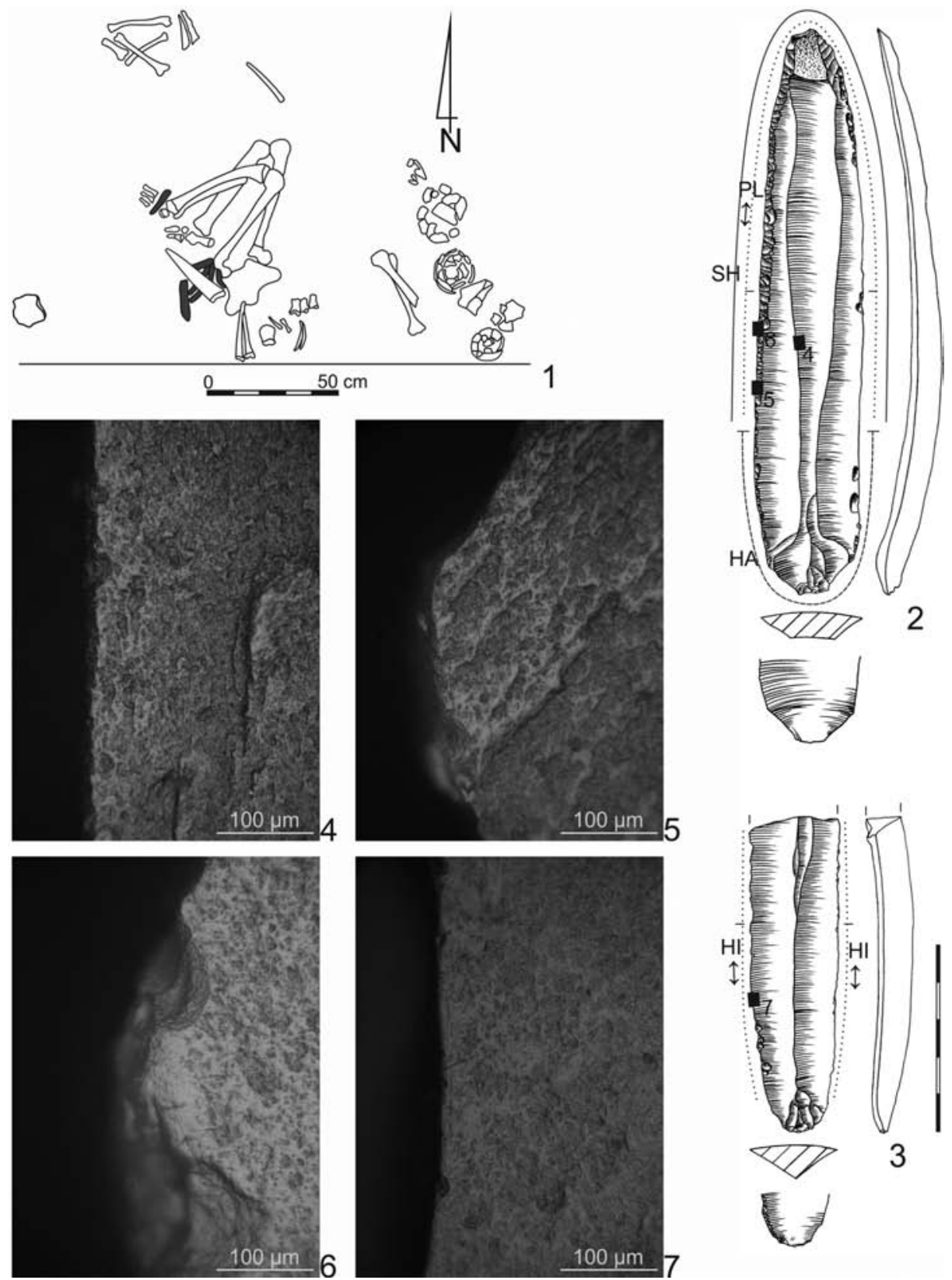

Fig. 5. Strzyżów 2A. 1 - plan of the grave No. 3; 2 - retouched blade; 3 - fragment of the blade; 4 - polish visible on the ridge, related to the storing of the retouched blade in the sheath; 5 - polish related to the cutting of plants; 6 - polish and linear traces visible on the edge, indicating using of the sheath, those traces cover earlier polish related to the cutting of plants; 7 - polish related to cutting of hide. Magnification $\times 200$ (objective $\times 20$ ). Drawn by A. Zakościelna, P. Mączyński, photographed by P. Mączyński 
Approximately 20 meters east from the central grave and 15 meters from boundary-grave No. 2, was located grave No. 7 (male, maturus), without grave-goods and which - in view of the multicultural nature of the site - weakened its connection with L-VC and the discussed cemetery. In any case, the outlines of burial pits weren't recorded. The bottom of the sewage tanks were flooded for several decades by waste from the sugar refinery, and was covered with 30-40 cm layer of calcium, culm and slag, and the soil under it was steeped in pollution. Flint products were recorded in the burial goods of five graves (No. 2-6).

Grave 3 - was located on the edge of the ditch running along the edge of sewage tank. The ditch had partially destroyed the bones of the skull and upper chest. The adult male's postcranial skeleton was flexed, with strongly bent legs, on the right side, with the head to the south-east (Fig. 5: 1). The grave goods consisted of 4 vessels in front of the skeleton, a bone dagger behind the left ilium, a bone awl at the height of knees, human skullcap cut of from the facial skeleton and placed behind the pelvis and 6 items made of Volhynian flint: retouched blade, 3 blades and retouched flake (Zakościelna 2010, tab. LIV). Based on the plan of the grave it can be only said that four of them lay behind the left ilium (probably in a pouch attached to a belt) under the bone dagger, and another flake was placed on the left metatarsal bones. Taking into account that the SE part of the grave was destroyed, we have to expect that the equipment is incomplete. Three artefacts were available for microwear analysis: retouched blade, completely preserved long blade and proximal part of another blade (Fig. 5: 2, 3; 6A: 1).

Flint inventory:

1. Semi-perforator retouched blade, in distal end formed with trough-like retouch, biscarred, facetted butt, domed bulb, scar of platform edge trimming, parallel course of edges, gradually come down at sharp, partially cortical tip, gently incurved in the middle part, trapezoidal in cross-section; dimensions: 159 x 28 x 9 mm (Fig. 5: 2).

2. Scarred blade with irregular course of one edge, multi-scared, facetted butt, scar of platform edge trimming, domed bulb, gently incurved in the middle part, triangular-trapezoidal in cross-section; dimensions: $129 \times 29 \times 7 \mathrm{~mm}$ (Fig. 6A: 1).

3. Proximal part of scared blade, bi-scarred, facetted butt, domed bulb, triangulartrapezoidal in cross-section; dimensions: $87 \times 24$ x 10 mm (Fig. 5: 3).

4. Lateral cortex blade, gently incurved in the middle part, triangular in cross-section, dimensions: $52 \times 18 \times 5$ mm (Fig. 6A: 2).

5. Scarred blade with a broken tip (?), gently incurved in the middle part, triangular in cross-section; dimensions: 38 × 8 x 4 mm (Fig. 6A: 3).

6. Retouched flake, dimensions: 31 x $21 \mathrm{~mm}$ (Fig. 6A: 4).

Grave 4 - preserved only in the form of a concentration of vessels, bone and flint products (Fig. 6B: 1). The burial goods were probably placed below the feet of the dead, but the skeleton was completely destroyed by the ditch, running along the edge of sewage tank. The concentration contained 8 vessels, preserved completely and in fragments, 8 items 

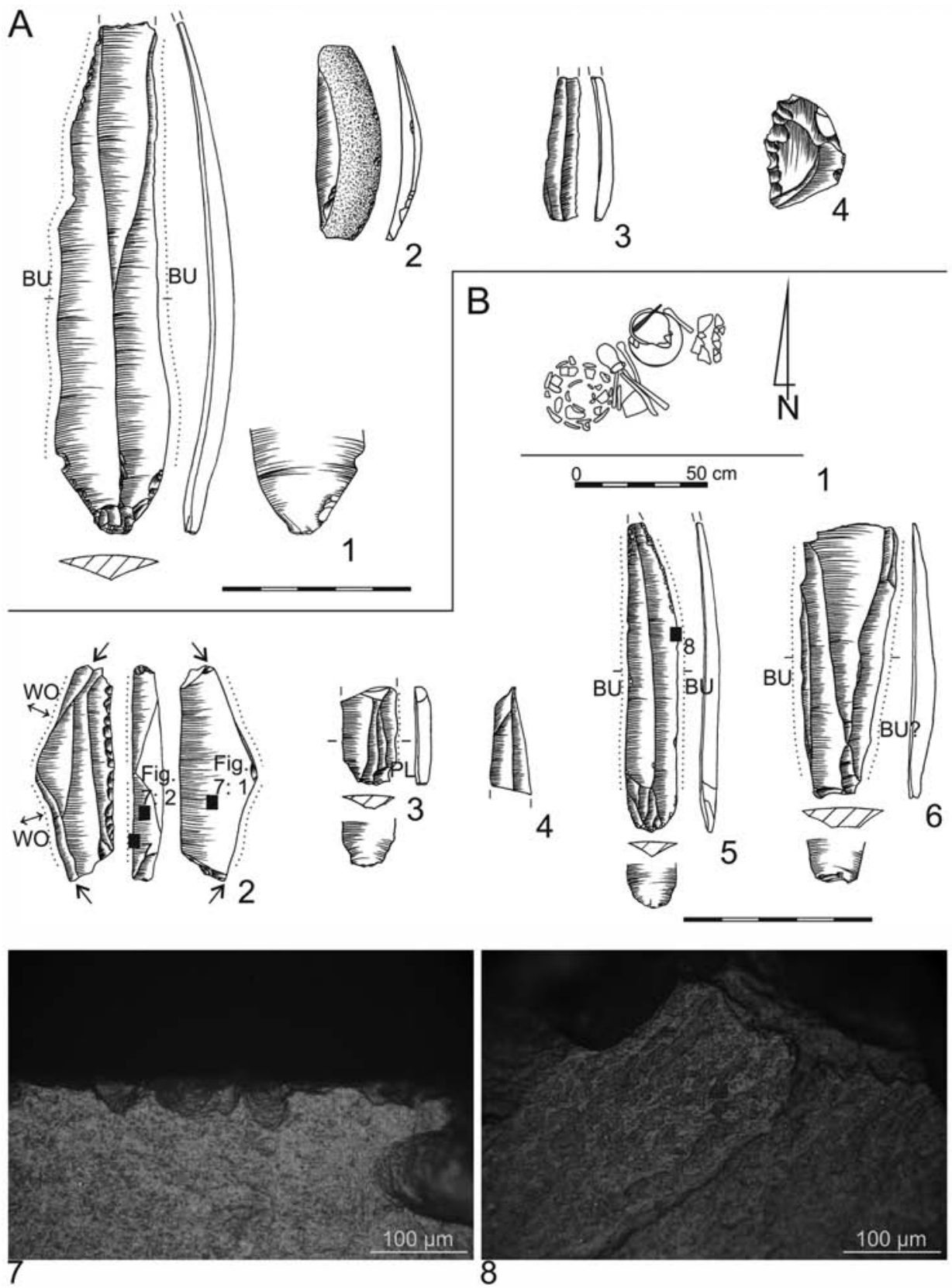

Fig. 6. Strzyżów 2A. A - inventory from grave No. 3: 1-3 - flint blades; 4 - retouched flake. B - grave No. 4: 1 - plan of the grave; 2 - burin; 3-6 - blades; 7 - traces related to the use of the edge of the burin as a wood-scrapper; 8 - traces of butchering visible on the edge of the blade. Magnification $\times 200$ (objective $\times 20$ ).

Drawn by A. Zakościelna, P. Mączyński, photographed by P. Mączyński 

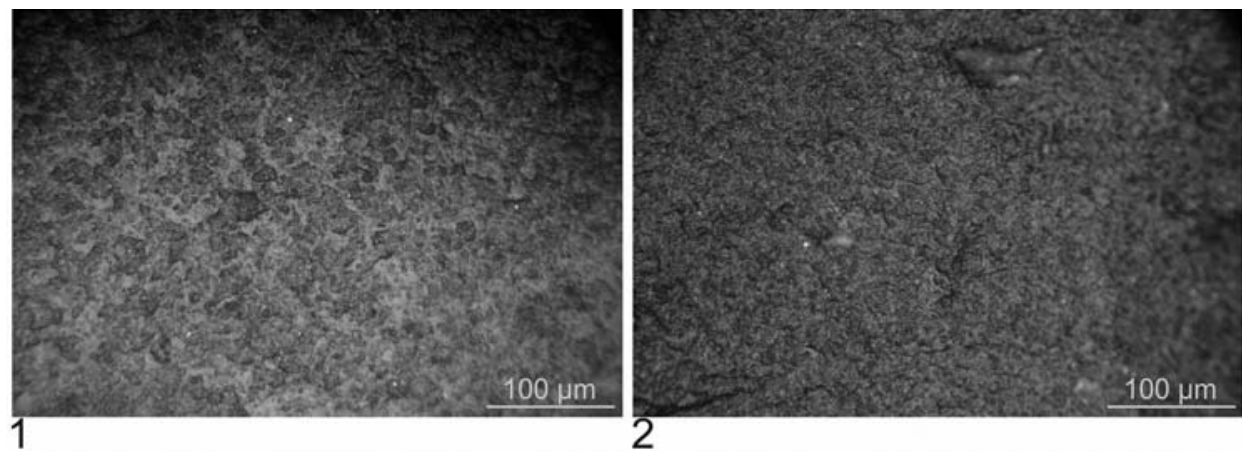

Fig. 7. Strzyżów 2A, grave No. 4: 1 - well-developed traces related to the use of the sheath; 2 - surfaces without visible use-wear traces. Magnification x200 (objective x20). Photographed by P. Mączyński

made of bone were located in the S-shaped vessel and 5 artefacts made of Volhynian flint (Zakościelna 2010, tab. LV, LVa). Four artefacts were available for microwear analysis: No. 1-3 and 5 (Fig. 6B: 2, 3, 5, 6).

Flint inventory:

1. Completely preserved scarred blade, facetted butt, slightly domed bulb, scar of platform edge trimming; straight in section, triangular in cross-section; dimensions: $82 \mathrm{x} 14 \mathrm{x}$ 4 mm (Fig. 6B: 5).

2. Scarred blade with slightly broken butt, slightly domed bulb, scar of platform edge trimming; straight in section, trapezoidal in cross-section; dimensions: $72 \times 24 \times 6 \mathrm{~mm}$ (Fig. 6B: 6).

3. Proximal fragment of bladelet, multi-scarred, facetted butt, slightly domed bulb; trapezoidal in cross-section; dimensions: 27 x 15 x 4 mm (Fig. 6B: 3)

4. Distal fragment of blade, triangular in cross-section; dimensions: $29 \times 11 \mathrm{~mm}$ (Fig. 6B: 4).

5. Multiple angle burin against a truncation made of blade with lateral retouch; dimensions: $57 \times 21 \times 8 \mathrm{~mm}$ (Fig. 6B: 2).

Grave 5 - discovered at a depth of $20 \mathrm{~cm}$ from the surface. The female (?) skeleton aged 35-40 years (maturus) lay in a flexed position on the left side, head to the south-east (Fig. 8A: 1). The burial goods consisted of 8 vessels, a blade of Volhynian flint, a bone awl, pieces of animal bone with traces of processing and polished stone (Zakościelna 2010, tab. LVI). The blade was located between the vessels, placed in front of the dead, at the height of shins (Fig. 8A: 1), and was subjected to microwear analysis (Fig. 8A: 2).

Flint inventory:

1. Scarred blade with broken butt, regular course of edges, gently incurved in the middle part, triangular in cross-section; dimensions: 138 x 21 x 7 mm (Fig. 8A: 2). 
A


B


$100 \mu \mathrm{m}$

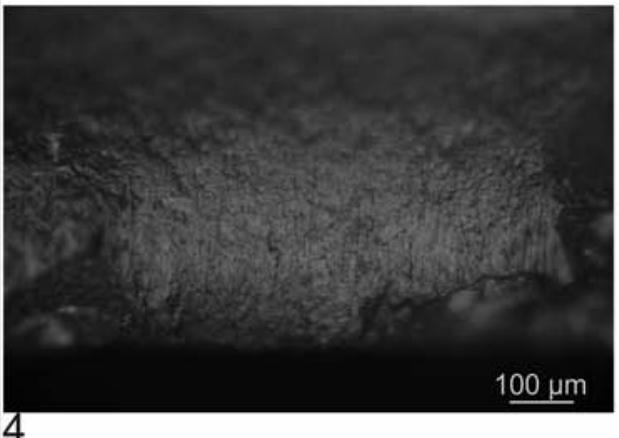

Fig. 8. Strzyżów 2A. A: 1 - plan of the grave No. 5; 2 - blade; 3 - use-wear traces visible on the edge of the blade, related to the cutting of meat. Magnification $\times 200$ (objective $\times 20$ ). B: 1 - plan of the grave No. 6; 2 - retouched flake; 3 - blade; 4 - use-wear traces visible on the edge, related to scraping of plants. Magnification x100 (objective x10). Drawn by A. Zakościelna, P. Mączyński, photographed by P. Mączyński 
Grave 6 - the arrangement of the very damaged skeleton suggests that the dead was an adult male (?), buried in a flexed position on the right side, head to the south-east (Fig. 8B: 1). At the foot of the skeleton stood 3 vessels, and between them a blade and a flake made of Volhynian flint (Zakościelna 2010, tab. LVII). The blade was subjected to microwear analysis (Fig. 8B: 3).

Flint inventory:

1. Blade with broken distal part, multi-scarred, facetted butt, highly domed bulb, scar of platform edge trimming; gently incurved in the distal part, trapezoidal in cross-section; dimensions: $119 \times 33 \times 8 \mathrm{~mm}$. The blade is broken into two pieces, probably in prehistory (Fig. 8B: 3).

2. Retouched flake; dimensions: 55 x 40 x 17 mm (Fig. 8B: 2).

\section{MICROWEAR ANALYSIS}

Trasaological analysis was performed with use of two types of microscopes. In the early stage of research the stereoscopic equipment by Carll Zeiss, Discovery V8, was used and which is capable of producing real magnifications from 10 to 80 times. The microscope was used together with a dedicated source of cold LED light. This first step involved searching and separating potentially used edges (Van Gijn 1989, 13). The next step in prospection was the observation of artefacts using the Meiji Techno MC-50T equipment. It is a metallographic microscope which allows for much larger magnifications: 50-500x. At this stage of study, the focus was placed on the observation of polish and linear traces. For the removal of fingerprints, the flint products were purified with acetone prior to analysis.

During traseological analysis, the focus was on two basic aspects of research. The first was based on the observation of butts and retouched edges, in order to locate and identify the traces related to the preparing of platform/platform edge of cores, and to identify the techniques used during the detachment of blades and retouching. The second research problem was the observation of traces related to the utilitarian uses of flint products. The focus was on an attempt to identify the type of raw material used, activities performed with the tool and the issue of using sockets and their storage in sheaths.

The surfaces of the observed products were characterized by their good state of preservation. Only in certain cases was the patina and post-deposition traces visible with use of microscope, in the form of small, segmented edge retouches (Fig. 2: 1, 2; 3: 2; 4: 2; 6A: 1; 8B: 3 ). Some difficulty was posed by the presence of numerous inventory records on the surfaces of all artefacts, and calcite precipitation present on a few forms of (Fig. 3: 1-3; 4: 1, 2; 5: 2; 6B: 5; 8A: 2). The applied method of microscopic analysis does not differ from the general assumptions used in this type of research (Van Gijn 1989, 13). Also, the conceptual system and terminology used in the work was based on the naming convention functioning in the literature of the subject (Van Gijn 1989, 3-8, 16-20; 2010, XV; Osipowicz 2010, 25-35 and further literature therein). 


\section{RESULTS OF MICROSCOPIC OBSERVATIONS}

The traseological analysis was made for all available flint artefacts, but this does not reflect the actual composition of inventories discovered in graves, as some of the forms were lost (cf. Presentation of materials). The studied group of artefacts is fairly uniform. The majority of the collection consists of blades and their fragments, of which 16 pieces were recorded together (the broken blade from grave No. 6 was treated as 2 items). Morphological tools are represented by 3 pieces, including a retouched blade, A burin made of retouched blade and an endscraper.

As already mentioned, the basic problem which was focused in the course of the analysis were attempts to determine the types of tools used for blade detachment and the application of correction retouch. An equally important issue was the identification of the type of activity performed with flint products.

The analysis of preserved butts in most cases did not reveal any traces of techniques used to obtain the blanks. Only on the butt of the macroblade from the grave No. 1/1961 from Strzyżów IA was a bright polish recorded, accompanied by numerous unidirectional linear traces, indicating a contact with bone or antler tool (Pyżewicz 2013, 31, and further literature). In the analyzed group, only 3 products had edges corrected by retouching. The study did not reveal any traces that could be helpful in identifying the fabricator used during the production of the tools.

More effective were the observations of cutting edges of blades and tools. As a result, it was possible to identify a number of activities performed with the flint products deposited in graves.

The most abundant collection of blades ( 8 pieces) comes from the grave $1 / 1961$ at site Strzyżów IA (Table 1). Some of the most interesting forms are two conjoining blades, where natural, unretouched edges located in the butt- and tip-parts of the blade were used during the work with them (Fig. 3: 4; 4: 1). Their surfaces are characterized by a very well developed filing and rounded edges, to a degree that allows them to observe macroscopically. On the surface there is a very strong polish of a cratered topography and rough texture, completely wiping off the natural flint relief. Polish is also accompanied by parallel linear traces, perpendicular to the cutting edge, indicating function of scraping (Fig. 4: 4). It seems that these tools could have been used in the hide-working process (Keeley 1980, 49-50; Van Gijn 1989, 28-30; Hayden 1979; 1993, 124-130). The genesis of observed traces can also be related to the long-term processing of plant fibers, resulting in the emergence of utility traces with very similar characteristics as those described above (Osipowicz 2010, $90,95)$. Ultimately, the issue of the origin of these changes has not been resolved unequivocally. It is worth noting that for the user of these tools it was more convenient to use the natural incurving of distal part, as evidenced by the stronger intensity of the traces located in this section of the blades (Fig. $3: 4 ; 4: 1$ ). 
Table 1. Strzyżów IA. The results of traseological analysis of inventory from grave No. 1/1961

\begin{tabular}{|l|l|l|l|}
\hline & \multicolumn{1}{|c|}{$\begin{array}{c}\text { Morphological } \\
\text { definition }\end{array}$} & \multicolumn{1}{|c|}{ The results of functional analysis } & Figure \\
\hline 1 & blade & $\begin{array}{l}\text { planing of hard material of animal origin } \\
\text { animal carcass processing } \\
\text { processing of plants } \\
\text { traces of bearing/wrapping }\end{array}$ & $2: 2,4$ \\
\hline 2 & blade & $\begin{array}{l}\text { animal carcass treatment } \\
\text { traces of bearing/wrapping }\end{array}$ & $2: 5$ \\
\hline 3 & blade & $\begin{array}{l}\text { animal carcass treatment } \\
\text { traces of bearing/wrapping }\end{array}$ & $2: 3$ \\
\hline 4 & blade & $\begin{array}{l}\text { animal carcass treatment } \\
\text { traces of bearing/wrapping }\end{array}$ & $3: 1$ \\
\hline 5 & blade & $\begin{array}{l}\text { animal carcass treatment } \\
\text { traces of bearing/wrapping }\end{array}$ & $3: 2$ \\
\hline 6 & blade & hide/plant scraping & $3: 4$ \\
\hline 7 & blade & hide/plant scraping & $4: 1,4$ \\
\hline 8 & blade & $\begin{array}{l}\text { animal carcass treatment } \\
\text { traces of bearing/wrapping }\end{array}$ & $4: 2$ \\
\hline 9 & endscraper & $\begin{array}{l}\text { scraping/cutting of soft material of plant/animal origin } \\
\text { traces of bearing/wrapping }\end{array}$ & $4: 3$ \\
\hline
\end{tabular}

The remaining blades found in the grave do not bear such strongly developed traces of use (Fig. $2: 3 ; 3: 1-3 ; 4: 2$ ). However, on their side edges the well developed use retouch, indicating a cutting function, can be observed. Those traces are accompanied by an edgepolish of marginal range. The observed polish most likely should be related to the use of the blades as knives for animal carcasses processing (Keeley 1980, 53-55; Moss 1983, 93; 1985; Vaughan, 38).

Additionally, on one of the forms were found a few bright linear traces, perpendicular to the edge of the blade, indicating the contact of the surface with hard material of animal origin. It is possible that the observed utility changes are related to the use of this part of blade as a scraper/rabot for hard material processing (Fig. 2: 4). Moreover, on these forms the polish is visible in a limited range, i.a. to more distal fragments, such as ridges, surface of the bulb and tip, where it is usually more intense (Fig. 2: 5). Such distribution of traces is probably related to the geometry of the blades. In such cases, it is suggested to interpret them as traces of transportation/wrapping or the use of sheaths made of soft materials (Rots 2010, pl. 90, 91). Such an interpretation is also the enhancement by the presence of flat-textured, bright polish on few forms, whose marginal range is limited to the very edge (Fig. 2: 3; 3: 1, 3). Such traces can be interpreted as proof of the use of sockets or wrappings made of plant origin materials (Rots 2010, pl. 195). 
It is also worth noting that on the lateral edges of all described forms occur very well developed micro-retouch with quite diverse characteristics. This is a close/irregular, bilateral, usually multistage, differentiated retouch. Its morphology does not seem to be in harmony with the types of polish that are recorded on the artefacts. However, it should be noted that many factors may influence the retouch, and this type of change is not considered a good indicator of function (Vaughan 1985, 16). Undoubtedly, a certain part of it has a nature related to work (cutting) or to transportation and use of the wrapping. It seems, however, that the cause of its origin should also be seen in the long, nearly sixtyyears operation of the artefacts in scientific circulation. During this time, the products were subjected to numerous analyzes and for some time used as didactic aids, which certainly affected the state of preservation of the objects.

Due to the poor recognition of traces visible on the observed blades, most of them were classified as short-lived tools. It is also very likely that these traces may appear as a result of their storage in sheaths or using wrappings.

The only morphological tool in the inventory from grave No. 1/1961 from Strzyżów IA is an endscraper made of a massive blade (Fig. 4: 3). This item was used as a scraper for processing (scraping, cutting) soft material of animal and plant origin. Such a function of the tool is confirmed by the presence of heavy developed traces on one of the edges, in the form of one- or two-staged retouch with feathered terminations, polish of domed-cratered topography, accompanied by parallel linear traces, perpendicular to the edge of the blade. Additionally, on the lateral edges and exposed surfaces strongly developed changes in the form of polish and rubbing were observed, related to the use of sheaths or wrapping (Fig. 4: 5). It is worth noting that there are no traces of use on the endscraper front, their absence suggests that the application of this procedure was intended to shape rather than prepare the cutting edge.

We observe a different situation in the case of grave inventories discovered at site $2 \mathrm{~A}$ in Strzyżów - a total amount of 9 flint artefacts from graves No. 3, 4, 5 and 6 were analyzed. The studied collection include mainly blades and their fragments which were used mainly for processing of soft or medium soft material of plant and animal origin, often the edges were used for different types of work. Piece of blade discovered near the legs of the individual buried in grave No. 3 are characterized by the presence of very well developed use-wear traces (Fig. 5: 3). On both sides of the tool one- or two-stage retouch with feathered termination is visible, and medium range polish of cratered topography, which at the edge completely erase the natural texture of the flint. These changes are accompanied by linear traces in the form of scratches oriented parallel to the edge of the blade (Fig. 5: 7). The observed changes most probably should be related to the use of the blade as a knife for cutting hide, however due to the heavy development of the observed marks, it is also possible that it was used on different types of material (Osipowicz 2010, 47-49). Another blade originating from that inventory, located on the hips of the dead, is characterized by the presence of poorly developed use-wear traces on both edges, indicating animal carcass 
Table 2. Strzyżów site 2A. The functional analysis of flint products discovered in the graves No 3-6

\begin{tabular}{|l|l|l|l|l|}
\hline & Location & \multicolumn{1}{|c|}{$\begin{array}{c}\text { Morphological } \\
\text { definition }\end{array}$} & \multicolumn{1}{|c|}{ The results of functional analysis } & \multicolumn{1}{|c|}{ Figure } \\
\hline 1 & Grave 3 & perforator blade & $\begin{array}{l}\text { cutting of plants } \\
\text { bearing in sheath } \\
\text { socket }\end{array}$ & $\begin{array}{l}5: 2,5,6 \\
5: 4,6\end{array}$ \\
\hline 2 & Grave 3 & blade & animal carcass processing & $6 \mathrm{~A}: 1$ \\
\hline 3 & Grave 3 & fragment of blade & cutting of various materials, i. a. hide & $5: 3,7$ \\
\hline 4 & Grave 4 & blade & animal carcass processing & $6 \mathrm{~B}: 5,8$ \\
\hline 5 & Grave 4 & blade & animal carcass processing & $6 \mathrm{~B}: 6$ \\
\hline 6 & Grave 4 & fragment of blade & processing of plants & $6 \mathrm{~B}: 3$ \\
\hline 7 & Grave 4 & burin & $\begin{array}{l}\text { retouched blade phase - traces of } \\
\text { sheath/storing } \\
\text { burin phase - scraping of wood }\end{array}$ & $6 \mathrm{~B}: 2 ; 7: 1,2$ \\
\hline 8 & Grave 5 & blade & cutting of meat & $6 \mathrm{~B}: 7$ \\
\hline 9 & Grave 6 & blade & $\begin{array}{l}\text { scraping of plants } \\
\text { cutting of organic material }\end{array}$ & $8 \mathrm{~A}: 2,3$ \\
\hline
\end{tabular}

processing (Fig. 6A: 1). Similar function is shared by two blades located below the feet of the dead buried in grave No. 4 (Fig. 6B: 5, 6, 8). Another artefact discovered here - the butt-part of the blade - was probably used to process soft plant material (Fig. 6B: 3).

The macroblade deposited between the vessels located behind the legs of a woman (?) buried in grave No. 5 (Fig. 8A: 2) were used for different kind of activities. On one of the edges of this product the presence of polish was observed, penetrating the structure of flint (Fig. 8A: 3), probably related to the use of the tool as a knife for cutting meat (Keeley 1980, 53-55; Moss 1983, 93; Vaughan 1985; Osipowicz 2010, 49-53).

To the functional tools with fairly long life span could be included the blade from grave No. 6, which probably was broken in prehistory and is presently in two fragments (Fig. 8B: 3 ). The presence of the glue layer visible on the blade fracture makes it impossible to confirm the time of damage of the artefact by the microscopic observation. The traces observed in that piece indicate that it was most probably used as a tool for performing diverse work - cutting and scraping of plant and animal material. However, the most intense traces indicate, that it was used as scraper for plant processing, as evidenced by the presence of one-staged retouch with feathered terminations and polish of domed-cratered topography, accompanied by linear traces (Fig. 8B: 4).

The burin (Fig. 6B: 2) from grave No. 4 is very interesting. Typological and morphological analysis revealed, that primarily it was a retouched blade with at least one retouched side, secondly converted into a burin. The observed modification is often found in L-VC flint inventories, because the blades are usually massive in size and could be easily processed (Zakościelna 1996, 58, 63, 64). During the microscopic examination it was found 
that the side edges of the burin were used as wood scrapers (Fig. 6B: 7). This is evidenced by the numerous crushes and bright mid-range polish visible on the edge, accompanied by linear traces in the form of bright scratches (Van Gijn 1989, 30-32; Pyżewicz 2013, 40, 41; Shchelinskiy 2015, 34). More interesting is the analysis of surfaces related to a phase of using of the tool in the form of retouched blade. The preserved original edge doesn't have the typical traces of usage, but on both sides of this exemplar, bright polish of a rough texture is visible. On the ventral side, it has only a surface nature and gently rubs the microrelief of the flint (Fig. 7: 1). Instead on the dorsal side, it covers mainly the protruding points, side edge and ridges, in some places leading to the heavy abrasion of the natural flint texture. This type of change does not affect the younger scars created during the detachment of burin spalls (Fig. 7: 2). The genesis of these changes is most likely to be associated with the use of a sheath made of soft materials (Rots 2008, 57-59; 2010, pl. 90, 91).

Another examined form - the completely preserved retouched blade - was discovered near the hip of the male buried in the grave No. 3 (Fig. 5: 2). In that case, we were able to identify the well-developed utility traces. Practically throughout the entire length of both sides polish of a domed topography and flat texture is visible, accompanied by black scratches (Fig. 5: 5). Undoubtedly, they result from the contact with plants - it could be a plant cutting knife (i. a. Juel Jensen 1994, 33). In addition, at the edge, the form of the polish changes and the topography becomes increasingly craterous (Fig. 5: 6). Similar types of traces were also observed on the protruding points and ridges (Fig. 5: 4). These types of marks can be interpreted as traces of storage in a soft material container or in the use of sheaths (Rots 2010, pl. 90, 91). The retouched blade could have been additionally equipped with a handle, which may indicate the range of the deformation associated with the treatment of plants that are not observed in the proximal part (Fig. 5: 2).

When analyzing the functional aspects of tools, it may also be helpful to analyze the structure and distribution of flint products in particular grave units. Artefacts discovered in different places on the dead, on the one hand, shows the way of bearing them in life hanging on the neck, stored in the waistband - on the other hand, document the funeral rites - assembled near the head, on the feet or in vessels placed in their vicinity (cf. Zakościelna 2010, 168-172). The state of preservation of the burial objects from which the analyzed inventories are derived does not allow the full use of this data (see: Material presentation). Major difficulties brought the analysis of the most numerous of the studied flint inventories discovered in double-grave No. 1/1961 on cemetery Strzyżów IA. There were flint grave-goods on the man's side (behind the head, along the left humerus and the most - behind the feet), but we didn't have information as to which pieces from the set of eight long blades occupied the most prominent places, i.e. on the chest and behind the head. On the basis of the burial customs of the L-VC communities, it seems reasonable to assume that they were the longest blades. Both of these pieces were found to have traces of their use as knives for the processing of animal carcasses, furthermore they exhibit marks of storage in a case/bag or use of a soft material wrapping (Fig. 2: 5). Additionally, on one 
of the edges of the longer piece traces have also been discovered indicating short-term use as a rabot for a hard material of animal origin (Fig. 2: 4).

Other flint items, 6 blades and a macrolithic endscraper were deposited behind the feet of the dead. Two of these blades served the same function - they worked as skin or plant scrapers (Fig. $3: 4 ; 4: 1$ ), while the remaining 4 most likely were used to cut the animal carcass (Fig. $3: 1-3 ; 4: 2$ ). Also, traces of bearing or using a wrapping were observed on the surface of these forms. In the concentration behind the feet of the dead an endscraper was placed whose side edge was used to scrape and cut organic and/or animal material (Fig. 4: 3).

Slightly more detailed information on the location of flint products can be established for the inventory originating from the site 2A in Strzyżów. Unfortunately, the burial of an adult male with his sumptuous burial equipment located in the center of the cemetery (grave No. 3) is preserved only in half. The entire south-eastern part of the grave where the head and upper torso was placed was destroyed (Fig. 5: 1). Considering the amount and quality of burial goods, including the presence of artefacts as unique as the bone dagger (Zakościelna 2010, 291 and tab. LIV), it can be assumed that the inventory, including the flints, of this grave is incomplete. A set of several flint tools has been preserved, of which 3 blades, a retouched blade and probably a retouched flake were located in the concentration at the left hip, and one blade was deposited on the feet of the dead (Fig. 5: 1). The custom of bearing tools in a waist bag has already been documented in several L-VC male graves (Zakościelna 2008, 584; 2010, 169-172). In that case, the set consisted of a blade, most often used as a knife for the processing of an animal carcass (Fig. 6A: 1) and a massive retouched blade for cutting plants. The tool originally was equipped with a handle, while its blade was protected by a sheath made of hide or organic materials (Fig. 5: 2). While a piece of blade placed on the feet was most probably used as a knife for cutting several types of raw material of animal and - probably - plant origin (Fig. 5: 3, 7).

With the equally rich inventory had to be equipped the dead buried in grave No. 4 . Unfortunately, due to the severe damage caused by earthworks, only the northern part of the grave was preserved, including some of the burial goods probably located behind the feet of the dead. Between the vessels were discovered the tip of the blade and another two whole pieces of blades, which were used for the processing of the animal carcass (Fig. 6B: $5,6,8)$. Another piece was used to work with different types of material - the butt-part of blade - which served to process the plant material (Fig. 6B: 3). Also to this type of work was used the last of forms, a multiple burin, which was most likely used for wood scraping (Fig. 6B: 2, 7).

A much more modest set of grave-goods was provided to the female (?) buried in grave No. 5. Behind her feet, in the company of few ceramic vessels was placed the blade used for cutting meat (Fig. 8A: 2, 3).

In contrast, by the male (?) buried in the partially destroyed grave No. 6 a set of several vessels, accompanied by retouched flake and broken flint blade was discovered. The tool, destroyed probably in the prehistoric period, was used for the diverse processing of soft 
material of plant and/or animal origin (Fig. 8B: 3, 4). Also in this case the mentioned inventory was placed behind the legs of the dead.

In all the studied units there occurred tools with visible use-traces. Most of the products were used for light work, most likely connected with the cutting of the animal carcass. Only one form - the burin from grave No. 4 - was used for the processing of harder material, such as wood. The variety and nature of recorded traces may indicate that most of them were household instruments use for daily activities. Worth attention are the low intensity of traces preserved on most of the non-retouched blades, especially the longest one from grave 1/1961 in Strzyżów 2A, which may indicate short-term use.

\section{COMPARATIVE ANALYSIS}

The low quantity of the comparative database makes it difficult to compare the results obtained for the flint inventory from the graves in Strzyżów with the other available L-VC related collections. In the first place the clear point of reference are the results of traseological observations made for several forms from the cemetery of this culture in Książnice 2 (Wilk and Kufel-Diakowska 2016b). This comparison must, however, be limited because from the numerous flint inventory accompanying the burials discovered in this cemetery, only a series of retouched blades were selected for analysis, thus omitting the remaining items included to the grave goods. This is especially true for grave No. 5 , in which an adult male was buried with a very rich set of flint products, clearly separated by the way they were worn during his lifetime - a retouched blade dagger - was placed on the chest of the dead, along the left humerus, and another 11 items (raw blades and retouched tools) lay in a concentration behind the pelvis (Wilk 2006, 248, and fig. 3-5; Zakościelna 2006, fig. 1). Only a retouched blade dagger was subjected to traseological analysis.

Nevertheless, some aspects of the obtained results have been confronted with each other. On the part of the forms, very well developed use-traces of a utility character were discovered - above all on the retouched blade dagger from grave No. 5 and on two forms from grave No. 15, significantly different from this exclusive product (Wilk and Kufel-Diakowska 2016b, fig. 4 and 5, 6). In addition to the changes related to the varied processing of plant and animal material, traces indicating the use of sockets/handles and the storage of tools in soft cases have been identified (Wilk and Kufel-Diakowska 2016b, 162). Very similar evidence of flint functioning has been discovered on the artefacts from Strzyżów IA and 2A. The retouched blade from grave No. 3, the retouched blade from grave No. 4 secondarily recycled into a burin on a retouched blade, and most of the blades carry traces of sheaths made of plant or animal material. The observed resemblances indicate the use of similar methods for handling these objects by the L-VC population.

Another interesting convergence concerns the typological endscrapers from both cemeteries. Both in the case of a massive endscraper from the grave No. 1/1961 in Strzyżów IA 
and a piece from the grave No. 15 in Książnice 2, any traces indicating that the endscraper front was used wasn't recorded (Wilk and Kufel-Diakowska 2016b, 162). This may indicate that in both cases the sole procedure of endscraper front shaping was not related to the preparation of the working edge, but it was a kind of edge finishing of the tool, intended solely to give it the desired shape. Particularly interesting are the observations of the retouched blade dagger from grave 17 discovered on the chest of the dead, without any trace of use, which corresponds to one of the macroblades from the grave No. 1/1961 in Strzyżów 2A, also in the exposed location at the dead.

An interesting field for analogies to the results of traseological analysis of flint products from funeral contexts is the environment of the eneolithic Balkan-Danuan cultures, to which the L-VC funeral rites are traditionally referred, with its sex differentiation manifesting in the functioning of separate funeral norms for female and male and significant disproportions in the richness of the funeral goods (Lichter 2001; Kadrow 2008; 2011; Zakościelna 2010). In the eastern Balkans in late Hamangia culture, and then in the Varna culture, the tradition of equipping the dead, mostly men, with flint products was very strong (Sirakov 2002; Manolakakis 2005). Long and very long blades found in rich and very rich male graves in different places (except for the chest, reserved for scepters, pectorals and gold ornaments), are clearly included in prestige objects and combined with high social status, as the richer grave - the longer the blade (Manolakakis 2002, 15-16; Sirakov 2002, 226227). The long blades in the funeral rites of the Tiszapolgár and Bodrogkeresztúr cultures in the eastern part of the Carpathian Basin were similar (e.g. Bognár-Kutzián 1963, 110, fig. 2 and 373-375; Patay 1974, 11; 1978, 25, fig. 34). Flint inventories from both cultural backgrounds, especially from the largest cemeteries in Durankulak (Hamangia and Varna cultures), Varna (Varna culture) and Tiszapolgár-Basatanya (Tiszapolgár and Bodrogkeresztúr culture) in most cases have been subjected to trasaological analyzes (e.g. Csongrádiné-Balogh 2004; Gurova e.g. 2006; 2010; Skakun 2006). Tools of various functions have been identified, primarily for cutting soft materials - meat, hide, treatment of hides (scraping), plants and wood, rarely bones (scraping, sawing). There are relatively few harvesting tools and in most cases they accompanied the females (Csongrádiné-Balogh 2004, 31-32; Gurowa 2006, tab. 2, diagram 2; 2010, 2-5). Particularly interesting are the results concerning long and very long blades from the rich graves of adult males in the Varna cemetery. From a series of 46 pieces longer than $15 \mathrm{~cm}$ (including the longest 24, in the range of 20-25 cm, - 14 pieces, $25-30 \mathrm{~cm}-4$ pieces, 30-35 $\mathrm{cm}-4$ pieces, $35-40 \mathrm{~cm} \mathrm{-} 1$ piece, and longer than $40 \mathrm{~cm}-1$ piece), only 6 bear traces of use as knives for cutting plants and soft materials as meat, cloth or hide, on the rest of them were not identified any traces of work (Gurova 2010, 4-5). These results confirm the repeated opinions that the so-called super-blades were too long, slim and fragile to be effective tools - their role was primarily social (e.g. Manolakakis 2002; 2005; Gurowa 2006; 2010). 


\section{DISCUSSION}

Authors of the traseological analyzes of the flint products from Książnice 2 discuss the role of retouched blade daggers in the L-VC communities and question the possibility (credibility) of the assessment of social status on the basis of the richness of burial equipment. In their opinion, retouched blade daggers were useful or had a dual role: symbolicutilitarian. They were led to such an opinion primarily by the clear traces of use on the retouched blade dagger made of Volhynian flint, located on the chest of the male from grave No. 5 of the eastern, elite burial field. The second argument is, probably discovered in similar location, of a semi-retouched blade made of chocolate flint (no traces of use) from the much poorer grave No. 17, located near the western, egalitarian burial field (Wilk and Kufel-Diakowska 2016b, 163-164).

The thesis advanced in 2008 on the social importance of macrolithic blades and retouched blade daggers discovered on the chest of the dead (and more broadly: the social importance of macrolithic blade-making by reinforced pressure technique) was based on four main premises: 1. they come primarily from the graves of adult males (adultus, maturus, senilis), accompanied by other rich equipment; 2 . they are impressive in terms of their dimensions and high craftsmanship with trough-like retouch; 3. if they wear macroscopic traces of work, such as harvesting, then they are discovered in the vicinity of the waist or inside the vessels standing by the head; 4 . none of them were found in the settlement context (Zakościelna 2008; 2010, 164-166, 183-189). The notion of the symbolic-utilitarian function of retouched blade daggers has not raised any objections. The hypothesis about their prestigious role was not based on the assumption that they were covered by some particular taboo. However, there was a limitation to possess these unique items, which were available to only a small group of elite adult men and only they could use them for various activities. It is clear in light of analysis of the richness of male burial equipment and it does not change with the "individual" cases of poorer graves in which - as in the tomb of No. 17 in Książnice 2 - the most magnificent retouched blade daggers made of Volhynian flint have not been discovered (Zakościelna 2010, tab. 47). Regarding this object, it is regrettable that the remains of the deceased male were not analyzed anthropologically (sex of the dead is indicated by the position on the right side). It would be particularly important in this case to determine the age of death in the context of justifiable hypotheses of gaining status in the male line in the communities of L-VC (Zakościelna 2010, 214-215). The role of the retouched blade daggers cannot be viewed on the basis of particular observations and in isolation from the social order that emerges from the holistic analysis of the funeral rites of the people of that culture, and which is related to the traditions of the eneolithic Balkan-Danube cultures (Hamangia, Varna, Tiszapolgár and Bodrogkeresztúr), with their clear division of the world into masculine and feminine, dominant male status and highly complex social relationships (Lichter 2001; Kadrow 2008; 2009; 2011; Zakościelna 2010). In this world, male military unions and perhaps a knightly 
ethos likely functioned (Kadrow 2009, 296-302). Aspiring to these elite circles was possible after reaching the right age and consisted in demonstrating some special qualities (Kadrow 2010, 84; Zakościelna 2010, 214-215). For the Lublin-Volhynian culture there is no well-preserved enough series of male graves to determine the age range, which was one of the conditions for social advancement, can only be indicated that the average wealth grew with the age of the dead, and the graves of adult males (adultus and adultus/maturus-maturus) are wealthier than the graves of young men, not to mention children (Zakościelna 2010, 188-189). The corresponding calculations were made for the eneolithic cemetery in Tiszapolgár-Basatanya and indicate that among the population of the Tiszapolgár and Bodrogkeresztúr cultures using it, this interval occurs between 16/18 and 25/35 year of life, meaning late juvenis, adultus and early maturus (Vandkilde 2006, 404-410 after Kadrow 2010, 84). Perhaps the dead from grave 17 in Książnice 2 died at a stage in which he had already acquired the right to wear a retouched blade dagger on his breast, but had not yet achieved full social promotion, hence the poorer burial goods and only an imitation of this exclusive item made of chocolate flint.

\section{SUMMARY}

The stage of the functional analysis of L-VC flint materials, including those from burial inventories which have special significance for the consideration of social relations, status and prestige, has only been initiated. This field of research should be explored further, and the information obtained in the whole context of the socio-cultural behavior of the population of this culture may well complement the picture of that eneolithic world we try to imagine and reconstruct. On the other hand, it is important to keep in mind the limitations of the method itself and not to overstate the expectations, as Jolanta Małecka-Kukawka (2001, 183-184) has already pointed out regarding flint-based settlement materials and their importance for the reconstruction of economic systems.

\section{References}

Bognár-Kutzián I. 1963. The Copper Age Cemetery of Tiszapolgár-Basatanya (= Archaeologia Hungarica. S.N. 42). Budapest: Akadémiai Kiadó.

Csongrádiné-Balogh É. 2004. Pattintott kőeszközök rézkori sírokban. In G. Ilon (ed.), Ôskoros kutatók III. összejövetelének konferenciakötete. Halottkultusz és temetkezés. Szombathely: Vas Megyei Múzeumok Igazgatósága, 19-43.

Drobniewicz B. 1978. Analiza mikroskopowa zabytków z grobu kultury lendzielskiej (nr 1325) na stanowisku 17 w Pleszowie (Kraków-Nowa Huta). Sprawozdania Archeologiczne 30, 31-33.

Drobniewicz B. 1979. Analiza traseologiczne wyrobów krzemiennych z cmentarzyska kultury ceramiki sznurowej w Koniuszy, woj. Kraków. Sprawozdania Archeologiczne 31, 91-94. 
Głosik J. and Gurba J. 1963. Ogólne wyniki prac archeologicznych w Strzyżowie, pow. Hrubieszów, w 1961 r. Sprawozdania Archeologiczne 15, 358-365.

Gurova M. 2006. Prehistoric flints as grave goods/hoards functional connotations. Archaeologia Bulgarica 10, 1-14.

Gurova M. 2010. Connotations fonctionnelles des grandes lames chalcolithiques: Exemple de la Bulgarie. Archaeologia Bulgarica 14(2), 1-10.

Juel Jensen H. 1994. Flint tools and plant working, hidden traces of stone age technology. A use wear study of some Danish Mesolithic and TRB implements. Aarhus: Aarhus University Press.

Kadrow S. 2008. Gender-diferentlated burial Rites in Europe of the $5^{\text {th }}$ and 4 th millennia BC: attempt at traditional archaeological interpretation. Analecta Archaeologica Ressoviensia 3, 49-95.

Kadrow S. 2009. The Early Copper Age: socio-cultural proces in modern sociological interpretation. Analecta Archaeologica Ressoviensia 4, 265-302.

Kadrow S. 2010. Antropopresja, neodarwinizm, globalne zmiany klimatyczne i teoria rewolucji społecznej Habermasa. In S. Czopek and S. Kadrow (eds.), Mente et rutro. Studia archaeologica Johanni Machnik viro doctissimo octogesimo vitae anno ab amicis, collegis et discipulis oblate. Rzeszów: Instytut Archeologii UR, 61-90.

Kadrow S. 2011. Kupferzeitliche Sozialstrukturen. In S. Hansen and J. Müller (eds.), Sozialäologische Perspektiven: Gesellschaftlicher Wandel 500o-150o v. Chr. zwischen Atlantik und Kaukasus. Internationale Tagung 15.-18. Oktober 2007 in Kiel (= Archäologie in Eurasien 24). Mainz: Verlag Philipp von Zabern, 107-121.

Keeley L. H. 1980. Experimental determination of stone tool uses. A microwear analysis. Chicago: University of Chicago Press.

Kondracki J. 1981. Geografia fizyczna Polski. Warszawa: PWN.

Kulesza A. 2008. Ceramiczne materiały neolityczne ze stanowiska IA w Strzyżowie, pow. hrubieszowski. Wiadomości Archeologiczne 6o, 198-224.

Lichter C. 2001. Untersuchungen zu den Bestattungssitten des südosteuropäischen Neolithicums und Chalkolithicums (= Heidelberger Akademie der Wissenshaften, Internationale Interakademische Kommission für die Erforschung der Vorgeschichte des Balkans 5). Mainz am Rhain: Verlag Philipp von Zabern.

Małecka-Kukawka J. 2001. Między formą a funkcją. Traseologia neolitycznych zabytków krzemiennych z ziemi chetmińskiej. Toruń: Wydawnictwo Uniwersytetu Mikołaja Kopernika.

Manolakakis L. 2002. Funkciyata na golemite plastiny ot Varnenskiya nekropol. Arkheologiya 43(3), 5-17.

Manolakakis L. 2005. Les industries lithiques énéolithiques de Bulgarie (= Internationale Archäologie 88). Rahden/Westf.: Verlag Marie Leidorf GmbH.

Mączyński P. 2015. Use-wear analysis of the selected flints artifacts from Lublin-Volhynian culture settlement at site 7 in Las Stocki (Poland). In 12. Warsztaty Krzemieniarskie SKAM. Poznań, 17-18. 
Mączyński P. 2016. The problems of atypical utilisation traces identified on the flint artefacts from the selected sites of Lublin-Volhynian culture. In 13th Lithic Workshop of SKAM. 28th-30th of September, 2016. The lithic artifacts - methods and history of research. Wroclaw, 92.

Moss E. 1983. The functional analysis of flint implements. Pincevent and Pont d’Ambon: Two cases from the French Final Paleolithic (= British Archaeological Reports. International Series 177). Oxford: Archaeopress.

Osipowicz G. 2010. Narzędzia krzemienne w epoce kamienia na ziemi chetmińskiej. Studium traseologiczne. Toruń: Wydawnictwo Naukowe Uniwersytetu Mikołaja Kopernika.

Patay P. 1974. Die hochkupferzeitliche Bodrogkeresztúr-Kultur. Bericht der Römisch-Germanischen Kommision 55, 1-72.

Patay P. 1978. Das kupferzeitliche Gräberfeld von Tiszavalk-Kenderföld (= Fontes Archaeologici Hungariae). Budapest: Akadémiai kiadó.

Podkowińska Z. 1960. Badania w Strzyżowie, pow. Hrubieszów, woj. Lublin, w latach 1935-1937 oraz 1939. Archeologia Polski 5, 39-80.

Pyżewicz K. 2013. Inwentarze krzemienne społeczności mezolitycznych w zachodniej części Niżu Polskiego: Analiza funkcjonalna. Zielona Góra: Wydawnictwo Fundacji Archeologicznej.

Rots V. 2008. Hafting and raw materials from animals. Guide to the identification of hafting traces on stone tools. Anthropozoologica 43(1), 43-66.

Rots V. 2010. Prehension and Hafting Traces on Flint Tools: A Methodology. Leuven: Leuven University Press.

Shchelinskiy V. E. 2015. Traseologicheskiy metod izuchenya funktsii pervobytnykh izdeliy: sledy iznosa na orudiyakh, ikh interpretatsya i informativniye vozmozhnosti. Arheologicheskije vesti 21, 31-51.

Sirakov N. 2002. Flint artifacts in prehistoric grave-good assemlages from the Durankulak necropolis. In H. Todorova (ed.), Durankulak 2. Die prähistorischen Gräberfelder von Durankulak. Sofia: Deutsches Archäologisches Institut, 213-246.

Skakun N. N. 2006. Orudiya truda i hoziaystvo drevnezemledelcheskikh plemen Yugo-Vostochnoy Evropy w epokhu eneolita. Sankt-Peterburg: Nestor-Istoriya.

Skakun N. N., Florek M. and Zakościelna A. 2008. Skład wiórów z Krowiej Góry w świetle analizy traseologicznej. In W. Borkowski, J. Libera, B. Sałacińska and S. Sałaciński (eds.), Krzemień czekoladowy $w$ pradziejach. Materiaty z konferencji w Orońsku, o8-10.10.2003. (= Studia nad Gospodarka Surowcami Krzemiennymi $w$ Pradziejach 7). Warszawa-Lublin: PMA, UMCS, SNAP Oddział w Warszawie, 429-434.

Vandkilde H. 2006. Warriors and Warrior Institution in Copper Age Europe. In T. Otto, H. Thrane and H. Vandkilde (eds.), Warfre and Society. Archaeological and Social Anthropological Perspectives. Aarhus: Aarhus University Press, 393-422.

Van Gijn A. L. 1989. The wear and tear of flint. Principles of functional analysis applied to Dutch Neolithic assemblages. Analecta Praehistorica Leidensia 22, 7-182.

Van Gijn A. L. 2010. Flint in Focus. Lithic Biographies in the Neolithic and Bronze Age. Leiden: Sidestone Press. 
Vaughan P. C. 1985. Use-wear analysis of flaked stone tools. Tuscon: University of Arizona Press.

Wilk S. 2006. Graves of the Lublin-Volhynian Culture at Site 2 in Książnice District of Busko-Zdrój. 2004 Exploration Seasons. Sprawozdania Archeologiczne 58, 247-270.

Wilk S. and Kufel-Diakowska B. 2016a. The function of the Lublin-Volhynian culture retouched blade daggers in the light of the usewear analysis. In 13th Lithic Workshop of SKAM. 28th-3oth of September, 2016. The lithic artifacts - methods and history of research, Wrocław, 23.

Wilk S. and Kufel-Diakowska B. 2016b. The Lublin-Volhynian culture retouched blade daggers in light of usewear analysis of artefacts from burials at site 2 in Książnice, Poland. Archaeologia Polona 54, 137-151.

Zakościelna A. 1996 Krzemieniarstwo kultury wotyńsko-lubelskiej ceramiki malowanej. Lublin: Wydawnictwo UMCS.

Zakościelna A. 2006. Flint Inventory of Graves of the Lublin-Volhynia Culture on Site 2 in Książnice, Busko-Zdrój District. Sprawozdania Archeologiczne 58, 271-291.

Zakościelna A. 2008. Wiórowce-sztylety jako atrybuty pozycji społecznej mężczyzn kultury lubelskowołyńskiej. In J. Bednarczyk, J. Czebreszuk, P. Makarowicz and M. Szmyt (eds.). Na pograniczu światów. Studia z pradziejów międzymorza baltycko-pontyjskiego ofiarowane Profesorowi Aleksandrowi Kośko w 6o. rocznicę urodzin. Poznań: Wydawnictwo Poznańskie, 577-591.

Zakościelna A. 2010. Studium obrzq̨dku pogrzebowego kultury lubelsko-wotyńskiej. Lublin: Wydawnictwo UMCS. 